\title{
STRUCTURE OF NANAOMYCIN E, A NEW NANAOMYCIN
}

\author{
Masaji Kasai, Kunikatsu Shirahata* \\ Tokyo Research Laboratory, Kyowa Hakko Kogyo Co., Ltd., \\ 3-6-6, Asahimachi, Machida, Tokyo 194, Japan \\ Shinzo Ishit, Kazuyuki Mineura, Hirofuto Marumo \\ Fuji Factory, Kyowa Hakko Kogyo Co., Ltd., Suntogun, Shizuoka, Japan \\ Haruo TANAKa and Satoshi OMMURA* \\ Kitasato University, Minato-ku, Tokyo, Japan \\ (Received for publication January 26, 1979)
}

\begin{abstract}
A new component, nanaomycin $\mathrm{E}$, has been isolated from the culture broth of Streptomyces rosa var. notoensis, which had been found to produce nanaomycins A, B, C and D. Nanaomycin E was an epoxy derivative of nanaomycin A and was converted into nanaomycin $\mathrm{A}$ and 4a-epi-nanaomycin B by treatment with sodium hydrosulfite in an acidic aqueous solution. 4a-epi-Nanaomycin B was quantitatively converted into nanaomycin A under alkaline conditions.
\end{abstract}

We have previously reported the structures and biological characteristics of nanaomycins ${ }^{1 \sim 5}$, which are effective against mycoplasma, fungi and Gram-positive bacteria. Further investigations of the fermentation of Streptomyces rosa var. notoensis revealed that another new active component, nanaomycin E (I) was produced. This paper describes the structure and the conversion of this compound into 4a-epi-nanaomycin B (II) and nanaomycin A (III).

\section{Production and Isolation of Nanaomycin E}

For the production of nanaomycin E (I), Streptomyces rosa var. notoensis (FERM-P No. 2209) was used. The seed culture for the production of nanaomycins was obtained according to the method rejorted in the previous paper ${ }^{2}$. Fermentation was carried out using a 30-liter jar fermentor containing 18 liters of a medium for 3 days at $27^{\circ} \mathrm{C}$. The composition of the medium was $2 \%$ glucose, $1 \%$ meat extract, $0.5 \%$ sodium chloride and $0.3 \%$ calcium carbonate ( $\mathrm{pH} 7.0$ before autoclaving).

Culture broth (50 liters), obtained by incubation of Streptomyces rosa var. notoensis in three 30-liter jar fermentors, was used for the isolation of nanaomycin E (I). The culture broth, after the $\mathrm{pH}$ was adjusted to 4.5 with sulfuric acid, was extracted with ethyl acetate (50 liters). After separation of the organic layer, the crude powder of nanaomycins, obtained by evaporation of the organic layer, was chromatographed on a column of silica gel 2 liters, Kanto Chemical
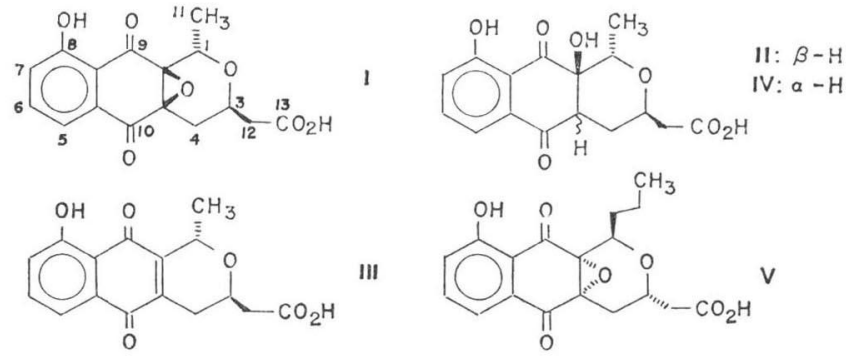

* To whiom all correspondence should be addressed. 
Co.) using a mixture of benzene and ethyl acetate (10:1). The fractions containing nanaomycin E (I) were combined and concentrated in vacuo to dryness to give a yellowish brown powder ( $8.8 \mathrm{~g}$ ). Concentration of a solution of the crude powder in 1 liter of $10 \%$ aqueous methanol afforded orange crystals of $\mathbf{I}$, which were collected $(7.9 \mathrm{~g})$ and recrystallized from $n$-hexane - dichloromethane to yield orange plates $(7.3 \mathrm{~g}), \mathrm{mp} 172 \sim 174^{\circ} \mathrm{C}$.

$$
\begin{array}{ll}
\text { Anal. Found: } & \text { C, } 60.14 ; \mathrm{H}, 4.34 \% \text {. } \\
\text { Calcd. for } \mathrm{C}_{16} \mathrm{H}_{14} \mathrm{O}_{7} \text { : } & \text { C, } 60.38 ; \mathrm{H}, 4.43 \% \text {. }
\end{array}
$$

Nanaomycin E (I) is soluble in methanol, ethanol, acetone and ethyl acetate and insoluble in $n$-hexane and petroleum ether. It was positive to a ferric chloride test. On silica gel thin-layer chromatography using chloroform - methanol (5:1) I showed a yellow fluorescent spot with Rf of 0.45 .

\section{Structure of Nanaomycin $\mathbf{E}$}

Nanaomycin E (I) has the following physical properties:

$[\alpha]_{1}^{44}+89.0^{\circ}(c 0.95, \mathrm{MeOH})$; IR $(\mathrm{KBr}) 3345(\nu \mathrm{OH}), 1728$ (carboxylic acid $\left.\nu \mathrm{CO}\right), 1683,1653 \mathrm{~cm}^{-1}$ (quinone $\nu \mathrm{CO})$; UV (MeOH) $236(\log \epsilon 4.38), 280^{\mathrm{sh}}(3.66), 364 \mathrm{~nm}(3.87) ;{ }^{13} \mathrm{C} \mathrm{NMR}^{*}\left(\mathrm{CDCl}_{3}-\mathrm{CD}_{3} \mathrm{OD}\right)$

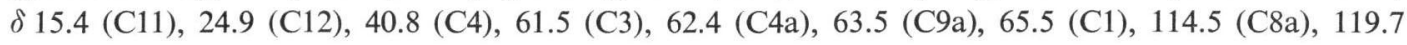
(C5), 124.0 (C7), 131.7 (C10a), 137.3 (C6), 161.9 (C8), 173.0 (C13), 190.0 (C10), 195.9 ppm (C9); ${ }^{1} \mathrm{H}$ NMR $\left(\mathrm{CDCl}_{3}\right) \delta 1.64\left(\mathrm{~d}, \mathrm{~J}=6.8 \mathrm{~Hz}, \mathrm{CH}_{3}\right), 1.94(\mathrm{dd}, \mathrm{J}=15.4,11.5 \mathrm{~Hz}, \mathrm{H} 4 \beta), 2.61(\mathrm{~d}, \mathrm{~J}=6.4 \mathrm{~Hz}$, $\mathrm{H} 12 \times 2), 2.92(\mathrm{dd}, \mathrm{J}=15.4,4.7 \mathrm{~Hz}, \mathrm{H} 4 \alpha), 4.15$ (m, H3), 4.77 (q, J=6.8 Hz, H1), 7.2 7.8 ppm (m, aromatic protons).

The molecular formula of $\mathbf{I}, \mathrm{C}_{16} \mathrm{H}_{14} \mathrm{O}_{7}$, was determined on the basis of its high resolution mass spectrum ( $\mathbf{M}^{+}, 318.0760$, calcd. 318.0739) and elemental analysis, showing that $\mathbf{I}$ had one more oxygen atom than nanaomycin A (III). In the IR spectrum of I, absorptions at 1683 and $1653 \mathrm{~cm}^{-1}$ due to the quinone carbonyls are shifted to higher wave numbers than those of III $\left(1645,1615 \mathrm{~cm}^{-1}\right)$. The ${ }^{13} \mathrm{C}$ NMR spectrum of $\mathbf{I}$ shows the large upfield shifts of 79.5 and $82.6 \mathrm{ppm}$ for C4a and C9a, respectively, compared with those of III $(141.9,146.1 \mathrm{ppm})$. These spectra suggest that I had a 2,3epoxy-1,4-naphthoquinone moiety. The fragmentations ( $m / e$ 303, 285, 229) and UV spectrum of I are similar to those of frenolicin $(\mathbf{V})^{8)}$, and ${ }^{1} \mathrm{H}$ NMR spectrum of $\mathbf{I}$ also resembles that of $\mathbf{V}$ excepting the chemical shifts of methyl and methine protons at $\mathrm{Cl}$. The structure $\mathbf{I}$ for nanaomycin $\mathrm{E}$ was supported by these data and chemical evidence described below.

\section{Conversion of Nanaomycin $\mathbf{E}$ into Nanaomycin A and 4a-epi-Nanaomycin B}

Treatment of I with sodium hydrosulfite in $0.1 \mathrm{~N}$ aqueous sodium hydroxide gave III, which was identical with an authentic sample (IR and optical rotation), in $87 \%$ yield. A similar reaction in $0.02 \mathrm{~N}$ hydrochloric acid (room temperature, 1.5 hours) gave, after silica gel column chromatography, II and III in $63 \%$ and $35 \%$ yields, respectively. Compound II was quantitatively converted into III under alkaline conditions, and gave a mixture of III and nanaomycin B (IV), an epimer of II, by heating at its melting point of $160^{\circ} \mathrm{C}$.

4a-epi-Nanaomycin B (II) is soluble in methanol, ethanol, acetone and ethyl acetate, and displays a positive ferric chloride test. The Rf value of II on silica gel thin-layer chromatography

* The assignments of $\mathrm{C} 5$ and $\mathrm{C} 7$ are determined according to those of the corresponding carbons of juglone derivatives ${ }^{6,7)}$. 
using chloroform - methanol (5:1) was 0.35. A pale yellow powder of II was obtained by crystallization from $n$-hexane - dichloromethane, $\mathrm{mp} 158 \sim 161^{\circ} \mathrm{C}$.
Anal. Found:
C, $59.76 ; \mathrm{H}, 5.03 \%$.
Calcd. for $\mathrm{C}_{16} \mathrm{H}_{16} \mathrm{O}_{7}$ :
$\mathrm{C}, 60.00 ; \mathrm{H}, 5.04 \%$.

4a-epi-Nanaomycin $\mathrm{B}$ (II) has the following physical properties: $[\alpha]_{\mathrm{D}}^{20}-109.1^{\circ}(c 1.08, \mathrm{MeOH})$; IR (KBr) 3490, $3200(\nu \mathrm{OH}), 1723$ (carboxylic acid $\nu \mathrm{CO}$ ), 1691, $1637 \mathrm{~cm}^{-1}$ (quinone $\nu \mathrm{CO}$ ); UV $(\mathrm{MeOH}) 233(\log \epsilon 4.35), 248^{\text {sh }}(4.04), 267^{\text {sh }}(3.70), 353 \mathrm{~nm}(3.74) ;{ }^{13} \mathrm{C} \mathrm{NMR}\left(\mathrm{CDCl}_{3}-\mathrm{CD}_{3} \mathrm{OD}\right)$ $\delta 16.3$ (C11), 24.9 (C12), 40.5 (C4), 50.3 (C4a), 64.1 (C3), 76.5 (C1), 77.1 (C9a), 116.7 (C8a), 118.5 (C5), 124.5 (C7), 136.1 (C10a), 137.9 (C6), 162.0 (C8), 173.4 (C13), 194. 2 (C10), 204.4 ppm (C9); ${ }^{1} \mathrm{H}$ NMR $\left(\mathrm{CDCl}_{3}-\mathrm{CD}_{3} \mathrm{OD}\right) \delta 0.96\left(\mathrm{~d}, \mathrm{~J}=7.2 \mathrm{~Hz}, \mathrm{CH}_{3}\right), 1.92(\mathrm{ddd}, \mathrm{J}=13.2,10.2,4.4 \mathrm{~Hz}, \mathrm{H} 4 \beta), 2.53(\mathrm{ddd}, \mathbf{J}=$ 13.2, 2, $2 \mathrm{~Hz}, \mathrm{H} 4 \alpha$ ) $, 2.55(\mathrm{~d}, \mathrm{~J}=6.2 \mathrm{~Hz}, \mathrm{H} 12 \times 2), 3.28$ (dd, J=4.4, $2 \mathrm{~Hz}, \mathrm{H} 4 \mathrm{a}), 3.96$ (q, J=7.2 Hz, $\mathrm{H} 1), 4.27$ (m, H3), $7.2 \sim 7.8 \mathrm{ppm}$ ( $\mathrm{m}$, aromatic protons).

The nolecular formula of II, $\mathrm{C}_{16} \mathrm{H}_{16} \mathrm{O}_{7}$, was determined by its mass spectrum $\left(\mathrm{M}^{+}, \mathrm{m} / \mathrm{e} 320\right)$ and elemental analysis. The transformation of II into III through loss of $\mathrm{H}_{2} \mathrm{O}$ was also found to occur in the mass spectrometer at $180^{\circ} \mathrm{C}$. The UV and ${ }^{13} \mathrm{C}$ NMR spectra of II resemble those of IV. In its ${ }^{1} \mathrm{H}$ NMR spectrum, upfield shifts of approximately $0.45 \mathrm{ppm}$ for both of the $\mathrm{Cl}$ methyl and methine protons were observed in comparison with those of IV. These large differences of the chemical shifts suggest that the methyl and methine protons are affected by the shielding of the aromatic and carbonyl groups. The above data, along with decoupling experiments and a DREIDING model lead to a suggested conformation of II as shown in Fig. 1.

\section{Biological Activity}

The antimicrobial spectra of nanaomycin E (I) and 4a-epi-nanaomycin B (II) are given in Table 1. Antimicrobial activities of $I$ are weaker than those of nanaomycin A. The acute toxicities ( $\left(\mathrm{LD}_{50}\right.$, i.p.) of $\mathbf{I}$ and $\mathbf{I I}$ in mice are 60 and $82.5 \mathrm{mg} / \mathrm{kg}$, respectively.

Fig. 1. The conformation of 4a-epi-nanaomycin B (II).

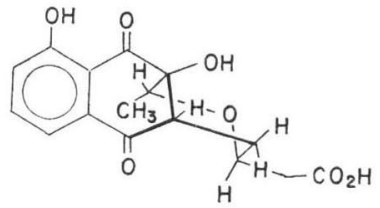

Table 1. Antimicrobial spectra of nanaomycin E (I) and 4a-epi-nanaomycin B (II).

\begin{tabular}{l|c|c}
\hline \multirow{2}{*}{ Test organisms } & \multicolumn{2}{|c}{$\begin{array}{c}\text { Minimal inhibitory } \\
\text { concentration } \\
(\mu \mathrm{g} / \mathrm{ml})^{*}\end{array}$} \\
\cline { 2 - 3 } & I & II \\
\hline Bacillus cereus & 12.5 & 12.5 \\
Staphylococcus aureus & 25 & 0.78 \\
$\quad$ FDA 209P & & 100 \\
Pseudomonas aeruginosa & $>100$ & 25 \\
Candida albicans & $>100$ & 1.56 \\
Trichophyton mentagrophytes & 50 & \\
\hline
\end{tabular}

* Estimated using an agar dilution technique.

\section{Discussion}

Streptomyces rosa var. notoensis, when grown in shake culture in a medium containing glucose instead of glycerol as carbon source, produced a new component, nanaomycin E (I). The antibiotic is an epoxy derivative of nanaomycin A (III), and is converted into III and 4a-epi-nanaomycin B (II) by treatment with sodium hydrosulfite.

Nanaomycin E (I) may be a precursor of nanaomycin B (IV).

From the biological point of view, it is of interest that the configuration at all chiral centers of $\mathbf{I}$ are opposite to those of frenolicin (V). This kind of relationship is also found between nanaomycin D and kalafungin ${ }^{5}$.

\section{References}

1) Ōmura, S.; H. Tanaka, Y. Koyama, R. Ōina, M. Katagiri, J. Awaya, T. Nagai \& T. Hata: 
Nanaomycins A and B, new antibiotics produced by a strain of Streptomyces. J. Antibiotics 27: 363 365,1974

2) Tanaka, H.; Y. Koyama, J. Awaya, H. Marumo, R. Ōina, M. Katagiri, T. Nagai \& S. Ōmura: Nanaomycins, new antibiotics produced by a strain of Streptomyces. I. Taxonomy, isolation, characterization and biological properties. J. Antibiotics 28: 860 867, 1975

3) Tanaka, H.; Y. Koyama, T. Nagai, H. Marumo \& S. Ōmura: Nanaomycins, new antibiotics by a strain of Streptomyces. II. Structure and biosynthesis. J. Antibiotics 28: 868 875, 1975

4) Tanaka, H.; H. Marumo, T. Nagai, M. Okada, K. Taniguchi \& S. Ōmura: Nanaomycins, new antibiotics produced by a strain of Streptomyces. III. A new component, nanaomycin C, and biological activities of nanaomycin derivatives. J. Antibiotics 28: 925 930, 1975

5) Ōmura, S.; H. Tanaka, Y. OKadA \& H. Marumo: Isolation and structure of nanaomycin D, an enantiomer of the antibiotic kalafungin. J. Chem. Soc., Chem. Comm. 1976: 320 321, 1976

6) Kobayashi, M.; Y. Terui, K. Tori \& N. Tsuji: Carbon-13 NMR spectra of juglone, naphthazarin and their derivatives. Tetrahed. Lett. 1976: 619 620, 1976

7) Tsuji, N.; M. Kobayashi, Y. Terui \& K. Tori: The structures of griseusins A and B, new isochromanquinone antibiotics. Tetrahedron 32: $2207 \sim 2210,1976$

8) Ellestad, G. A.; M. P. Kunstmann, H. A. Whaley \& E. L. Patterson: The structure of frenolicin. J. Am. Chem. Soc. 90: 1325 1332, 1968 